\title{
An Examination on Satisfaction Level of Employee Benefits at BMW Plant Chennai
}

\author{
Magdalene Peter, S. Fabiyola Kavitha, G. Thilrukshan
}

\begin{abstract}
The main objective of the study is to know the different types of Employee benefits offered by the company and to find the necessity of Employee benefits
\end{abstract}

Key words: Employees, Benefit

\section{INTRODUCTION}

The investigation is to find the Satisfaction of Employees on the benefits which is received from the company [1-3]

The Employee benefits are

1. Employment policies.

2. Remuneration benefits.

3. Retirement benefits.

4. Social security.

5. Employee welfare.

6. Employee engagement.

- Employment policies: [4-6]

Employee policy covers such as

1. Leave policies.

2. Working hours.

- Remuneration benefits: $[7,8]$

Remuneration benefits covers such as

1. Incentives.

2. Bonus.

- Retirement benefits:[9]

Retirement benefits covers such as

1. Provident fund.

2. Gratuity.

- Social security: [10]

Social security benefits covers such as

1. ESI.

2. Medical insurance.

- Employee welfare: [11]

Employee welfare covers such as

1. Food.

2. Transport.

3. Uniform.

- Employee engagement:

Employee engagement covers such as

1. Recreation activities. possible.

\section{OBJECTIVE}

\section{A. PRIMARY OBJECTIVE}

- To find the Satisfaction of Employees on the benefits which is received from the company.

\section{B. SECONDARY OBJECTIVE}

- To find the different types of Employee benefits offered by the company.

- To find the necessity of Employee benefits.

\section{NEED OF THE STUDY}

- To know the approach of the company towards employees.

- To know the requirements of employees.

- To know advantage of Employee benefits.

\section{SCOPE OF THE STUDY}

- To know about the Employee benefits

- To know the different types of Employee benefits.

- To recognize the satisfaction level of the Employees.

\section{LIMITATIONS OF THE STUDY}

- The survey was taken from the employees of BMW

- The time required for survey is more.

- $\quad$ Few employees are hesitated to give there feedback.

\section{REVIEW OF LITERATURE}

Savery (1989) featured the activity fulfillment of medical attendants in Perth, Western Australia. The activity fulfillment level of the medical attendants was predominantly because of intriguing and testing work which was trailed by a sentiment of accomplishment wherein, he even said compensation was positioned as a low satisfier. The activity fulfillment level expanded as the individual developed old where in the factors like sex, time in emergency clinic, position held were controlled [12-17]. Associations ought to consistently concentrate on fulfilling the three fundamental needs (Individual sparks, Employee connections and individual connections) of a worker which will consequently help the

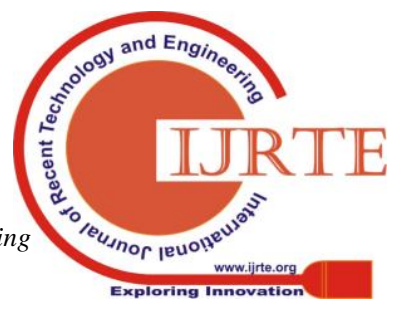


representatives in accomplishing work fulfillment.

Melvin (1993) expressed that the ecological plan of an association assumes a significant job in occupation fulfillment simultaneously it likewise assumes a significant job in workers high employment contribution.

The creator even refers to that it is the duty of the administration to structure nature in such a way, that it diminishes the disappointment where in the work undertakings, working examples are appropriately referenced [18-22].

MacDermid(1999) contemplated the activity fulfillment level of compulsive workers. He said there are six factors of obsessive worker designs for example Obsessive workers, Enthusiastic Workaholics, Work Enthusiastic, Unengaged Workers, Relaxed Workers and Disenchanted Workers [23-25] The activity fulfillment level and profession fulfillment level was significantly more in Enthusiastic Workaholics , Work Enthusiastic, Relaxed Workers than Workaholics, Unengaged Workers and Disenchanted Workers on account of things to come vocation prospects, working inclusion, drive and work delight [26].

Beumont (1982) in his article highlights the job satisfaction level of general household in United States \& Britain where in there is a close fit relationship in U.S than Britain. In the study he found that in U.S there is a positive relationship between Job Satisfaction and Age where as in Britain it was considerably low [27].

Savery (1987) features the impact of sparks on employment fulfillment. He states characteristic inspirations' aides in accomplishing work fulfillment. The manager helps in expanding the fulfillment level by offering a greater amount of inborn inspirations like testing work and vocation advancement to the subordinates and he is the person who gives the most unmistakable help to the subordinate[28, 29]. Singh and Jain (2013) features on workers work fulfillment and its effect on their presentation. Workers' disposition mirrors the lesson of the organization. Workplace is the key factor in occupation fulfillment. Great workplace and great working conditions prompts work fulfillment simultaneously helps in expanding representative work execution, benefit, consumer loyalty just as maintenance [30].

\section{RESEARCH METHODOLOGY}

\section{A. RESEARCH DESIGN}

The research design used in this study was descriptive research design.

\section{B. DATA COLLECTION}

- Primary data was collected through structured questionnaire.

- Secondary data was gathered from Books \& Magazines [31,32]

\section{SAMPLING METHOD}

Sampling Method used for this study was non probability purposive sampling

\section{STATISTICAL TOOLS}

- Statistical tools used for this study was Percentage analysis [33].
VIII. RESULTS AND DISCUSSION

TABLE NO: 1 TABLE SHOWINGFEEDBACK ON LEAVE POLICIES

\begin{tabular}{|l|l|l|l|}
\hline & $\begin{array}{l}\text { Leave } \\
\text { policies }\end{array}$ & $\begin{array}{l}\text { No of persons } \\
\text { responded }\end{array}$ & $\begin{array}{l}\text { of } \\
\text { responded }\end{array}$ \\
\hline Bad & 0 & 25 & 0 \\
\hline $\begin{array}{l}\text { Neither } \\
\text { nor }\end{array}$ & 2 & 25 & 8 \\
\hline Good & 23 & 25 & 92 \\
\hline
\end{tabular}

INFERENCE:

Nearly $92 \%$ of the employees feedback is Good, $8 \%$ of the employees feedback is Neither nor.

\section{CHART NO: 1 CHART SHOWING THE FEEDBACK ON LEAVE POLICIES}

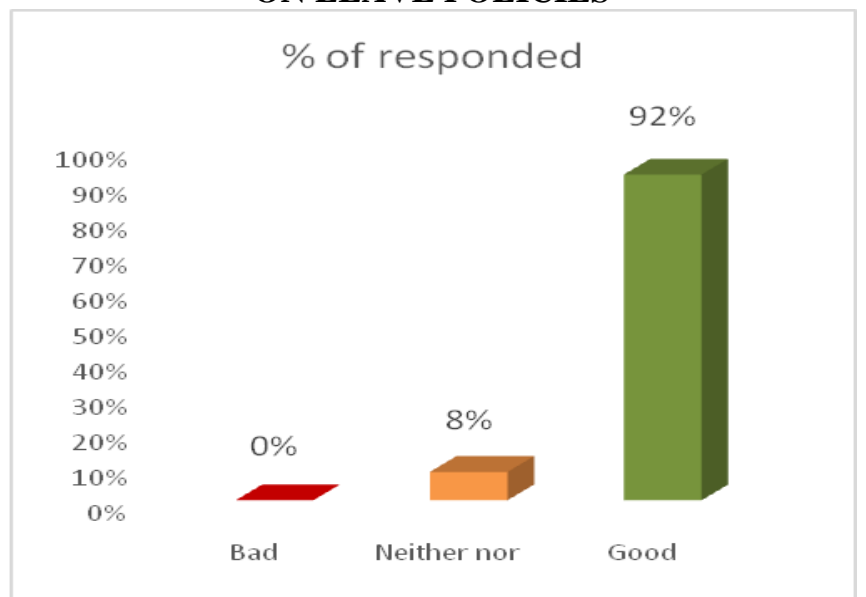

TABLE NO: 2 SHOWING FEEDBACK ON WORKING HOURS

\begin{tabular}{|l|l|l|l|}
\hline & $\begin{array}{l}\text { Working } \\
\text { hours }\end{array}$ & $\begin{array}{l}\text { No of persons } \\
\text { responded }\end{array}$ & $\begin{array}{l}\text { of } \\
\text { responded }\end{array}$ \\
\hline Bad & 0 & 25 & 0 \\
\hline Neither nor & 0 & 25 & 0 \\
\hline Good & 25 & 25 & 100 \\
\hline
\end{tabular}

INFERENCE:

$100 \%$ of the of the employees feedback is Good.

\section{CHART NO: 2 CHART SHOWING THE FEEDBACK ON WORKING HOURS}

\section{INFERENCE:}

$100 \%$ of the of the employees feedback is Good. 


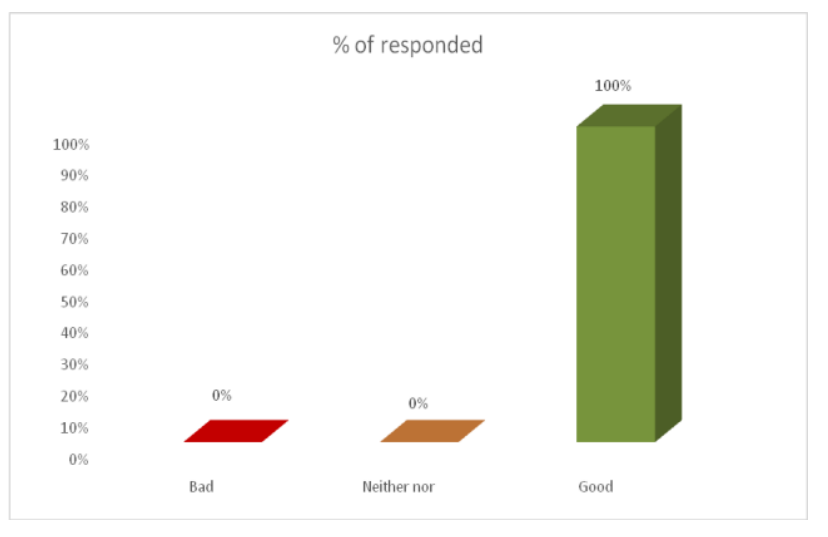

CHART NO: 3 CHART SHOWING FEEDBACK ON INCENTIVES

\begin{tabular}{|c|c|c|c|}
\hline \multicolumn{4}{|c|}{$\%$ of responded } \\
\hline \multicolumn{4}{|l|}{$90 \%$} \\
\hline \multicolumn{4}{|l|}{$80 \%$} \\
\hline \multicolumn{4}{|l|}{$70 \%$} \\
\hline \multicolumn{4}{|l|}{$60 \%$} \\
\hline \multicolumn{4}{|l|}{$50 \%$} \\
\hline \multicolumn{4}{|l|}{$40 \%$} \\
\hline \multicolumn{4}{|l|}{$30 \%$} \\
\hline \multirow{2}{*}{\multicolumn{4}{|c|}{$10 \%$}} \\
\hline & & & \\
\hline \multicolumn{4}{|c|}{ Neither nor } \\
\hline \multicolumn{4}{|c|}{ TABLE NO: 3 TABLE SHOWING FEEDBACK ON } \\
\hline \multicolumn{4}{|c|}{ BONUS } \\
\hline & Bonus & $\begin{array}{l}\text { No of } \\
\text { persons } \\
\text { responded }\end{array}$ & $\begin{array}{l}\% \quad \text { of } \\
\text { responded }\end{array}$ \\
\hline Bad & $\mathrm{O}$ & 25 & $\mathrm{O}$ \\
\hline Neither & & & \\
\hline nor & 2 & 25 & 8 \\
\hline Good & 23 & 25 & 92 \\
\hline
\end{tabular}

INFERENCE:

Nearly $92 \%$ of the employees s feedback is Good, $8 \%$ of the employees feedback is Neither nor.

CHART NO: 4 CHART SHOWING FEEDBACK ON BONUS

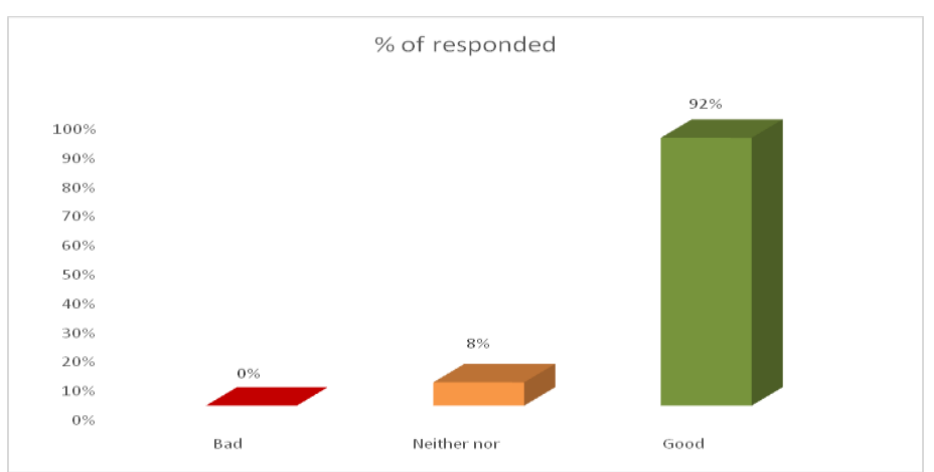

TABLE NO: 4 TABLE SHOWING FEEDBACK ON INCENTIVES

\begin{tabular}{|l|l|l|l|}
\hline & No of & $\begin{array}{l}\text { Nersons } \\
\text { Incentives }\end{array}$ & $\begin{array}{l}\text { of } \\
\text { responded } \\
\text { responded }\end{array}$ \\
\hline Bad & 0 & 25 & 0 \\
\hline $\begin{array}{l}\text { Neither } \\
\text { nor }\end{array}$ & 3 & 25 & 12 \\
\hline Good & 22 & 25 & 88 \\
\hline
\end{tabular}

INFERENCE:

Nearly $88 \%$ of the employees feedback is Good, $12 \%$ of the employees feedback is Neither nor.

\section{TABLE NO: 5 TABLE SHOWING FEEDBACK ON PROVIDENT FUND}

\begin{tabular}{|l|l|l|l|}
\hline & $\begin{array}{l}\text { Provident } \\
\text { fund }\end{array}$ & $\begin{array}{l}\text { Norsons of } \\
\text { responded }\end{array}$ & $\begin{array}{r}\% \\
\text { of }\end{array}$ \\
\hline Bad & 0 & 25 & 0 \\
\hline $\begin{array}{l}\text { Neither } \\
\text { nor }\end{array}$ & 0 & 25 & 0 \\
\hline Good & 25 & 25 & 100 \\
\hline
\end{tabular}

INFERENCE:

$100 \%$ of the of the employees feedback is Good. 
CHART NO: 5 CHART SHOWING FEEDBACK ON PROVIDENT FUND

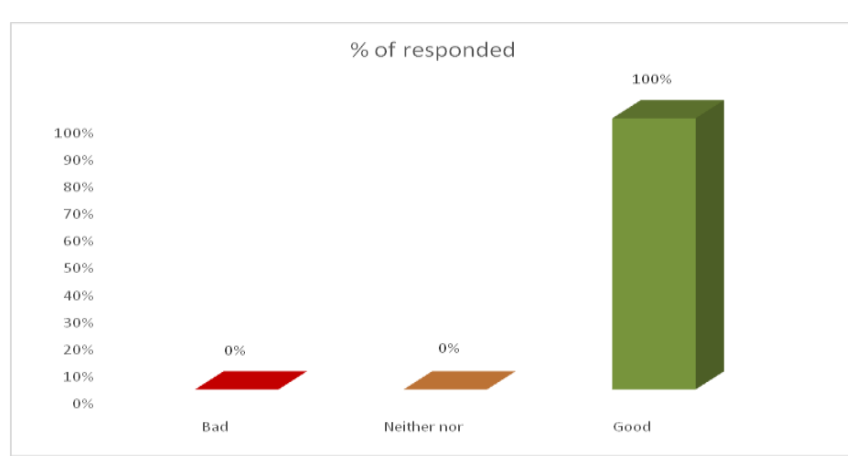

TABLE NO: 6 TABLE SHOWING FEEDBACK ON GRATUITY

\begin{tabular}{|l|l|l|l|}
\hline & Gratuity & $\begin{array}{l}\text { No of } \\
\text { persons } \\
\text { responded }\end{array}$ & $\begin{array}{r}\% \text { of } \\
\text { responded }\end{array}$ \\
\hline Bad & 0 & 25 & 0 \\
\hline Neither nor & 0 & 25 & 0 \\
\hline Good & 25 & 25 & 100 \\
\hline
\end{tabular}

INFERENCE:

Nearly $100 \%$ of the employees feedback is Good.

\section{CHART NO: 6 CHART SHOWING FEEDBACK ON} GRATUITY

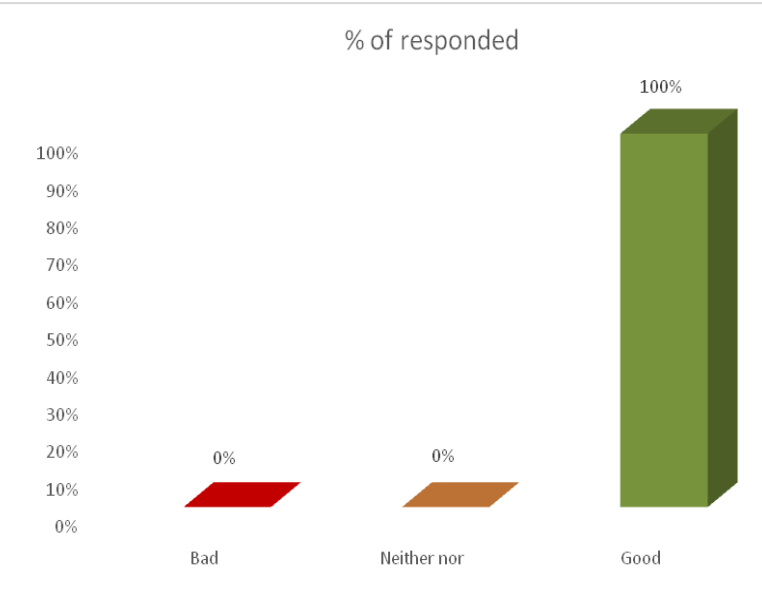

TABLE NO: 7 TABLE SHOWINGFEEDBACK ON ESI

\begin{tabular}{|l|l|l|l|}
\hline & ESI & $\begin{array}{l}\text { No of } \\
\text { persons } \\
\text { responded }\end{array}$ & $\begin{array}{l}\% \\
\text { responded }\end{array}$ \\
\hline Bad & 0 & 25 & 0 \\
\hline Neither nor & 1 & 25 & 4 \\
\hline Good & 24 & 25 & 96 \\
\hline
\end{tabular}

INFERENCE:

Nearly $96 \%$ of the employees feedback is Good, $4 \%$ of the employees feedback is Neither nor.

\section{CHART NO: 7CHART SHOWING FEEDBACK ON ESI}

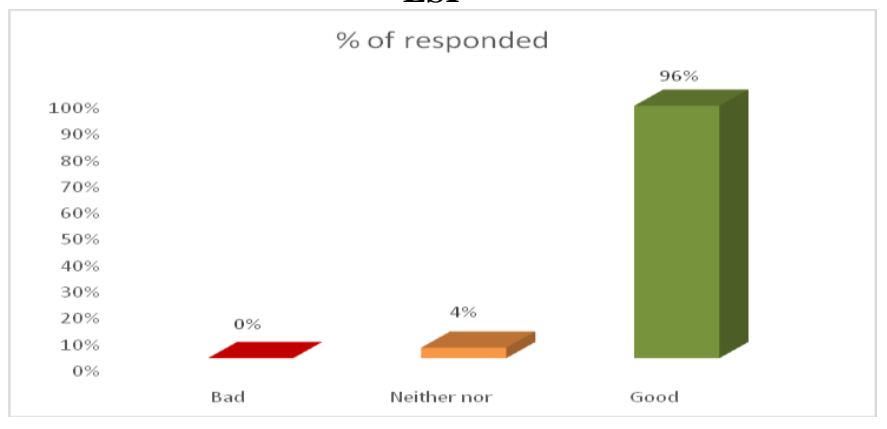

IX. FINDING

1) People are prefer to work in BMW Group because of Good employees welfare measures, Resanable salary packages and Brand name.

\section{SUGGESTION}

The suggestion for BMW Group is to maintain the Employee satisfaction level as best as possible, To increase the involvement and production.

\section{CONCLUSION}

Success of BMW Group of companies is mainly due to the Employees best effective involvement in maintaining the quality as assured by them to the customers fullest satisfaction.

\section{REFERENCES}

1. BharthVajan R., Ramachandran S.,Psychographic dimensions of training,2016,International Journal of Pharmacy and Technology,V-8,I-4,P-23727-23729

2. Balakrishnan P., Bharthvajan R.,A study on human resource planning in hospitals in Chennai City,2014,International Journal of Applied Engineering Research,V-9,I-22,P-7503-7507

3. Priyadarsini P., Bharthvajan R.,Role of emotional intelligence training programme in reducing the stress of the nurses,2014,International Journal of Applied Engineering Research,V-9,I-22,P-7411-7421

4. Kerinab Beenu G., Bharthvajan R.,Empirical analysis on the cosmetic buying behavior of young women in South India,2014,International Journal of Applied Engineering Research,V-9,I-22,P-7361-7366

5. Balakrishnan P., Bharthvajan R.,Whistling in the wind,2014,International Journal of Applied Engineering Research,V-9,I-22,P-7586-7593

6. Krishnan B., Peter M.,Health hazards of Indian Bpo employee-an alarming issue,2014,International Journal of Applied Engineering Research,V-9,I-22,P-7336-7341

7. Kerinab Beenu G.H., Peter M.,Role of insurance in economic development,2014,International Journal of Applied Engineering Research,V-9,I-22,P-7532-7539

8. Balakrishnan P., Peter M., Priyadarsini P.,Efficiency of safety measures for wellbeing of employees in manufacturing 
industry,2014,International Journal of Applied Engineering Research,V-9,I-22,P-7376-7382

9. Anbarasi M., Praveen Kumar S.,Online sales promotions of herbal products and its effectiveness towards tanisha.com,2019,Indian Journal of Public Health Research and Development,V-10,I-1,P-195-200

10. Anbarasi M., Praveen Kumar S.,Various online marketing and promotions strategies to improve the validation towards the organic products in the pharmaceutical sectors,2019,Indian Journal of Public Health Research and Development,V-10,I-1,P-263-269

11. Loganathan R., Praveen Kumar S.,Grievance handling a key factor for solving issues of employees in an organization,2014,International Journal of Applied Engineering Research,V-9,I-22,P-7483-7491

12. Loganathan R., Praveen Kumar S.,Study on preference of private label brands in super and Hypermarkets, 2014,International Journal of Applied Engineering Research,V-9,I-22,P-7327-7335

13. Smitha M., Praveen Kumar S.,Understanding stress and its managementamong the nurses in Chennai city,2014,International Journal of Applied Engineering Research,V-9,I-22,P-7560-7565

14. Kerinab Beenu G.H., Praveen Kumar S.,A study on the investment behavior of Chennai investors in mutual fund schemes,2014,International Journal of Applied Engineering Research,V-9,I-22,P-7520-7525

15. Loganathan R., Praveen Kumar S.,Retention strategies key for organizational productivity,2014,International Journal of Applied Engineering Research,V-9,I-22,P-7443-7447

16. Pavithra J., Ganesan M., Brindha G.,State wise analysis of microfinance sector in India,2016,International Journal of Pharmacy and Technology, V-8,I-4,P-23417-23432

17. Pavithra J., Ganesan M.,A comparative study on microfinance in India and abroad,2016,International Journal of Applied Business and Economic Research,V-14,I-8,P-5471-5476

18. Pavithra J., Ganesan M.,A study on awareness and impact of micro-financial schemes, 2016,International Journal of Applied Business and Economic Research,V-14,I-8,P-5449-5460

19. Senthilmurugan P., Pavithra J.,Consumer preference towards organised retailing with reference to $\mathrm{Big}$ Bazaar,2014,International Journal of Applied Engineering Research,V-9,I-22,P-7469-7475

20. Senthilmurugan P., Pavithra J.,Implication of social media marketing in growing healthcare industry,2014,International Journal of Applied Engineering Research,V-9,I-22,P-7448-7456

21. Loganathan R., Pavithra J.,Consumer perception towards private label brand over other brands in super markets and hypermarkets,2014,International Journal of Applied Engineering Research,V-9,I-22,P-7355-7360

22. Kerinab Beenu G., Pavithra J.,Tradeâ€"off between liquidity and profitability in logistics industry,2014,International Journal of Applied Engineering Research,V-9,I-22,P-7398-7401

23. Kerinab Beenu G., Pavithra J.,A study on the prospective consumerâ $\mathrm{E}^{\mathrm{TM}_{\mathrm{S}}}$ perception towards utility cars in Chennai city,2014,International Journal of Applied Engineering Research,V-9,I-22,P-7526-7531

24. Pavithra J., Dilli Babu P., Ambuli T.V.,A study on budgetary control at Maruti Service Masters, Chennai,2014,International Journal of Applied Business and Economic Research,V-12,I-2,P-151-161

25. Pavithra J., Dilli Babu P., Ambuli T.V.,A study on customer satisfaction of retro Garments Pvt Ltd, Chennai,2014,International Journal of Applied Business and Economic Research,V-12,I-2,P-381-391

26. Kerinab Beenu G.H., Pavithra J., Senthilmurugan P.,A study on the influence of promotional activities for TATA ARIA among consumers in Chennai,2014,International Journal of Applied Engineering Research,V-9,I-22,P-7572-7578

27. Vijayaragavan S.P.,An investigative expert that's general FBG sensors, International Journal of Mechanical Engineering and Technology,V-8,I-8,PP-1500-1505,Y-2017

28. Vijayaragavan S.P.,Equalization routing protocol for Wi-Fi sensor strategy,International Journal of Mechanical Engineering and Technology,V-8,I-8,PP-1662-1666,Y-2017

29. Karthik B., Kiran Kumar T.V.U., Vijayaragavan P., Bharath Kumaran E.,Design of a digital PLL using $0.35 \hat{I}^{1} / 4 \mathrm{~m}$ CMOS technology, Middle - East Journal of Scientific Research,V-18,I-12,PP-1803-1806,Y-2013

30. Kanniga E., Selvaramarathnam K., Sundararajan M.,Kandigital bike operating system,Middle - East Journal of Scientific Research, V

31. Jasmin M., Vigneshwaran T., Beulah Hemalatha S.,Design of power aware on chip embedded memory based FSM encoding in FPGA,International Journal of Applied

Research,V-10,I-2,PP-4487-4496,Y-2015

Engineering

32. Jasmin M.,Optimization techniques for low power VLSI circuits,Middle - East Journal of Scientific Research,V-20,I-9,PP-1082-1087,Y-2014

33. Jasmin M., Vigneswaran T.,Fuzzy controller for error control of on - Chip communication,2017 International Conference on Algorithms, Methodology, Models and Applications in Emerging Technologies, ICAMMAET 2017,V-2017-January,I-,PP-1-5,Y-2017

\section{AUTHORS PROFILE}

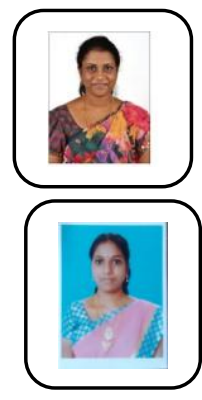

Magdalene Peter, Associate Professor, Department of Management Studies, Bharath Institute of Higher Education and Research, Chennai, India

S. Fabiyola Kavitha, Associate Professor, Departmen of Management Studies, Bharath Institute of Higher Education and Research, Chennai, India

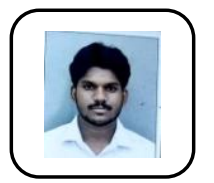

G. Thilrukshan, Student, Department of Management Studies, Bharath Institute of Higher Education and Research, Chennai, India 